\title{
In vitro Efficiency of Disinfectants Against Salmonella enteritidis Samples Isolated from Broiler Carcasses
}

\begin{tabular}{l} 
- Author(s) \\
\hline Cardoso MO' \\
Ribeiro AR' \\
Santos $L R^{\prime \prime \star}$ \\
Borsoi $A^{\prime}$ \\
Pilotto F' \\
Rocha SLS' \\
Nascimento VP' \\
' Centro de Diagnóstico e Pesquisa em \\
Patologia Aviária. Faculdade de Veterinária. \\
Universidade Federal do Rio Grande do Sul, \\
Porto Alegre, RS. \\
' Faculdade de Agronomia e Medicina \\
Veterinária - Curso de Medicina Veterinária \\
- Universidade de Passo Fundo (UPF), Passo \\
Fundo, RS.
\end{tabular}

Mail Address

LR Santos

Rua Uruguai, 154 - Apto 22

99010-110. Passo Fundo, RS, Brazil

Fone/Fax: (054) 33168485

E-mail: luruschel@upf.br

Keywords

Broiler carcasses, disinfectants, in vitro resistance, Salmonella enteritidis.

\section{ABSTRACT}

The threat to public health represented by Salmonella is at least partially a consequence of its ecology in poultry hosts. Good manufacturing practices in the processing plant can reduce the contamination of poultry products, and critical control point principles are essential throughout the chain production. One procedure adopted in critical points control to prevent and to reduce Salmonella in farms and poultry products is the use of disinfectants. This study aimed at evaluating disinfectant efficiency against Salmonella enteritidis samples isolated from broiler carcasses in Rio Grande do Sul State between 1995 and 1996. The tested disinfectants were: phenol 1:256, quaternary ammonium 1:2500, glutaraldehyde 1:200, and iodine 1:500, with contact times of 5, 10, 15, and 20 in an in vitro test. .Phenolic compounds showed better results, iodine and glutaraldehyde showed intermediary results, and quaternary ammonium presented efficiency at all contact times evaluated in the in vitro test.

\section{INTRODUCTION}

Many food-borne pathogens pose risk to public health, and the genus Salmonella is particularly important due to its ecology in the birds that carry them. Salmonella parathyphus is typically associated to asymptomatic diseases, and present different colonization patterns in the intestinal tract of birds.

Good manufacturing practices in processing plants may reduce final product contamination, and the control of critical points is essential along the entire production chain (Bailey et al., 2001). One of the mechanisms adopted in the control of critical points to control and to reduce the presence of Salmonella spp during broiler processing and in the final product is the use of disinfectants. A wide range of active principles, such as chlorine, quaternary ammonium, glutaraldehyde, and iodine, is available for the use in poultry production, both during rearing and processing.

The expected efficacy of disinfectants depends on their correct application, considering recommended dilutions, time of contact with the surface to be sanitized, previous removal of organic matter, the quality of the water used for cleaning, and general characteristics of the action of disinfectants (Berchieri Jr. \& Barrow, 1995; Davison et al., 1996; Martinez et al., 1999), in addition to product concentration, and environment temperature and $\mathrm{pH}$ (Merianos, 1991).

Improper food handling and neglecting water treatment in the presence of microorganisms - pathogenic or not - can increase equipment contamination problems due to the formation of biofilms, which protect these microorganisms and increase up to 100 fold their resistance to disinfectants (Lillard, 1993 apud Davies \& Wray, 1995). 
The present study aimed at evaluating the efficiency of disinfectants commonly used in poultry processing plants in the presence of Salmonella enteritidis samples isolated from broiler carcasses in the state of Rio Grande do Sul in 1995 and 1996.

\section{MATERIAL AND METHODS}

Eighty Salmonella enteritidis samples isolated from carcasses of broilers processed in Rio Grande do Sul, Brazil, between 1995 and 1996, were collected. Carcasses were processed according to the method established in Ordinance 08 (Brasil, 1995), at the Avian Pathology Diagnosis and Research Center (CDPAUFRGS), and the final identification of serovars was carried out at Oswaldo Cruz Institute.

The disinfectant efficiency evaluation test was carried out according to the Microbiological Methods Manual for Foods (Brasil, 1992). The collected Salmonella enteritidis samples were placed in $\mathrm{BHI}$ broth (Brain Heart Infusion, Merck) and incubated for 18-24h. Samples were then diluted at $10^{-1}$ to $10^{-10}$ in peptone water at $0.1 \%$, and colony-forming units (CFU) per milliliter ( $\mathrm{ml}$ ) were counted in BHA medium (Brain Heart Agar, Difco). The 1:100 dilution, with $10^{5}$ to $10^{7}$ CFU/ $\mathrm{ml}$, was selected for efficiency tests. The following disinfectants and their respective concentrations were tested: phenol 1:256, quaternary ammonium 1:2500, glutaraldehyde 1:200, and iodine 1:500, which are the concentrations commonly used in poultry processing companies. Disinfectants were diluted in distilled water, and $9 \mathrm{ml}$ were distributed in sterile tubes. To each tube, $1 \mathrm{ml}$ organic matter (whole milk submitted to UHT treatment) and $10 \mu \mathrm{L}$ of the 1:100 dilution of stationaryphase culture were added. Solutions were homogenized, and 5, 10, 15, and 20 minutes of exposure were counted, seeding $10 \mu \mathrm{L}$ in $\mathrm{BHI}$ broth. Tubes were incubated at $37^{\circ} \mathrm{C}$ for 96 hours. Tubes were checked for turbidity and film formation on the surface or precipitation in the bottom of the tube, and those considered positive were seeded in Salmonella selective media for confirmation.

The results were submitted to the test of Cochran (Siegel, 1975).

\section{RESULTS AND DISCUSSION}

Table 1 shows the efficiency of disinfectants against the 80 Salmonella enteritidis (SE) samples isolated from broiler carcasses in 1995 and 1996, in Rio Grande do Sul, Brazil. In the present study, glutaraldehyde was the most efficient (93.75\%) after 15 minutes of contact against SE samples. Both phenol and iodine started to act after 10 minutes, but phenol presented 100\% efficiency, whereas iodine, 91.25\%. Quaternary ammonium acted only on $8.75 \%$ of SE samples, even after 20 minutes of contact.

\begin{tabular}{lccc}
\hline Table 1 - Performance of disinfectants after 5, 10, 15, and 20 \\
minutes of contact against 80 Salmonella enteritidis samples \\
isolated from broiler carcasses between 1995 and 1996, in Rio \\
Grande do Sul, Brazil. & & & \\
Commercial & Contact & n. of resistant & Resistence \\
product & time & strains & percentage \\
*Glutaraldehyde 1:200 & $5^{\prime}$ & 35 & $43.75 \%$ \\
& $10^{\prime}$ & 15 & $18.75 \%$ \\
& $15^{\prime}$ & 5 & $6.25 \%$ \\
*Iodine 1:500 & $20^{\prime}$ & 4 & $5.00 \%$ \\
& $5^{\prime}$ & 33 & $41.25 \%$ \\
& $10^{\prime}$ & 9 & $11.25 \%$ \\
*Phenol 1:256 & $15^{\prime}$ & 7 & $8.75 \%$ \\
& $20^{\prime}$ & 4 & $5.00 \%$ \\
& $5^{\prime}$ & 16 & $20.00 \%$ \\
1:2500 & $10^{\prime}$ & 5 & $6.25 \%$ \\
& $15^{\prime}$ & 0 & $0 \%$ \\
& $20^{\prime}$ & 0 & $0 \%$ \\
\hline
\end{tabular}

(*) Significance: $p<0.05$.

Berchieri Jr. and Barrow $(1995,1996)$ found that phenolic compounds and glutaraldehyde are efficient against Salmonella spp., and also reported that quaternary ammonium compounds were inefficient.

In high concentrations, phenol breaks the cell wall and precipitates proteins, and in low concentration, it inactivates essential enzymes, being considered bacteriostatic in small quantities ( $\mathrm{O}^{\prime}$ Connor \& Rubino 1999). The bacteriostatic capacity of phenol may have contributed for the better performance of this product in 15 minutes of contact with SE samples.

Glutaraldehyde has wide spectrum and rapid action, even in the presence of organic matter. In addition, it does not corrode plastic and metal. Its biocidal activity is due to its effect on protein synthesis and to its capacity of destroying spores (Heit \& Riviere, 1995; Scott \& Gorman, 1991).

The low reactivity of iodine with protein and its disinfection capacity in a wide range of $\mathrm{pH}$ (it maintains its activity in the presence of organic matter and at $\mathrm{pH}<4$ ) are the main reasons for its utilization (Gottardi, 1991; Heit \& Riviere, 1995). However, some disadvantages limit its use, such as changes of metal surfaces not resistant to oxidation and its absorption by some plastics, resulting in brown spots (Gottardi, 1991). In the present study, iodine presented similar or 
higher efficiency as compared to glutaraldehyde at 5 , 10, 15, and 20 minutes of contact. Also, it was more efficient than quaternary ammonium, but less efficient than phenols at these same times.

Conner and Eckman (1997) compared alkaline and acid phenolic compounds, and observed that alkaline phenols were less efficient than acid phenols. On the other hand, bactericide activity was not reduced when those disinfectants were applied in a shuttle program.

In the present study, quaternary ammonium presented low efficiency at all tested times against SE. However, when Leite (2002) tested the efficiency of quaternary ammonium and sodium hypochloride against samples of Salmonella enteritidis, $S$. typhimurium, $S$ hadar, and $S$ heidelberg isolated from broiler carcasses, he observed that quaternary ammonium had better performance as compared to sodium hypochloride. In addition, among the tested samples, SE was the serovar that showed the highest resistance to quaternary ammonium.

In the present study, disinfectants were individually evaluated; however, the use of a single active principle for long periods of time may impair its efficiency. Therefore, in vitro tests with disinfectants may aid in the control of the efficiency levels obtained with different active principles, and underscores the importance of using the proper concentrations of products with proven efficiency against the targeted microorganisms.

\section{CONCLUSION}

It was concluded that disinfectants based on glutaraldehyde, phenol, and iodine were 95\% efficient or more against Salmonella enteritidis; however, disinfectants based on quaternary ammonium presented very low efficiency.

\section{REFERENCES}

Bailey JS, Cox NA, Stern NJ. HACCP Symposium. Risk Management factors associated with implementation of HACCP in poultry industry [cited 2005 ago 20]. Available from: http:// www.cfsan.fda.gov.

Berchieri Jr A, Barrow PA. The effects of chemical disinfectants and sanitizers on Salmonella Gallinarum. Revista de Microbiologia 1995; 26(4):246-252.

Berchieri Jr A, Barrow PA. The antibacterial effects for Salmonella enteritidis phage type 4 of different chemical disinfectants and cleaning agents tested under different Conditions. Avian Pathology 1996; 25:663-673.
Brasil. Ministério da Agricultura e do Abastecimento. Secretaria e Defesa Agropecuária. Método analítico de carcaças de aves e pesquisa de Salmonella. Diário Oficial da União. Brasília. Portaria n. 8, 23 janeiro 1995, Seção 1:1182-1184.

Brasil. Ministério da Agricultura e do Abastecimento. Manual de métodos microbiológicos para alimentos. Brasília: Coordenação Geral de Laboratório Animal; 1992.

Conner DE, Eckman MK. Rotación de desinfectantes en plantas de incubar. Avicultura Professional 1997; 15(2):21-22.

Davies RH, Wray C. Observations on disinfection regimens used on Salmonella Entritidis infected poultry units. Poultry Science 1995; 74:638-647.

Davison S, Benson CE, Eckroade RJ. Evaluation of disinfectants against Salmonella enteritidis. Avian Disease 1996; 40:272-277.

Gottardi W. lodine and lodine Compounds. In: Block SS, editor. Disinfection, sterilization and preservation. $4^{\text {th }}$ ed. Philadelphia: Lea \& Febiger; 1991. p. 225-252.

Heit MC, Riviere JE. Antiseptics and disinfectants. In: Adams AR, editor. Veterinary pharmacology and therapeutics. $7^{\text {th }}$ ed. lowa: lowa State University; 1995. p. 741-752.

Leite CLC. Desinfecção química aplicada na avicultura: concentrações inibitórias mínimas de desinfetantes derivado da amônia quaternária e hipoclorito de sódio sobre Salmonella sp e Escherichia coli. Acta Scientiae Veterinariae 2002; 30(1):74-75.

Martinez F, Berchieri Jr A, Paulillo AC. Ação de desinfetantes sobre Salmonella na presença de matéria orgânica. Revista Brasileira de Ciência Avícola 1999; 1:17-35.

Merianos JJ. Quaternary ammonium antimicrobial compounds. In: Block SS, editor. Disinfection, sterilization ad preservation. $4^{\text {th }}$ ed. Philadelphia: Lea \& Febiger; 1991. p. 225-252.

O'Connor DO, Rubino JR. Phenolic ompounds. In: Block SS, editor. Disinfection, sterilization and preservation. $4^{\text {th }}$ ed. Philadelphia: Lea \& Febiger; 1999. p. 204-222.

Scott EM, Gorman SP. Glutaraldehyde. In: Block SS, editor. Disinfection, sterilization and preservation. $4^{\text {th }}$ ed. Philadelphia: Lea \& Febiger; 1991. p. 596-610.

Siegel S. O caso de K Amostras Relacionadas. In: Siegel S. Estatística não-paramétrica para as ciências do comportamento. São Paulo: McGraw-Hill; 1975. p.181-196. 